\title{
Jurisprudentie
}

\section{Vereniging van Eigenaars moet plaatsing scootmobiel in gemeenschappelijke ruimte toestaan}

Hof Amsterdam 5 maart 2019 (ECLI:NL:GHAMS:2019:767)

Mr. D.C. Houtzager*

\section{Feiten}

Een echtpaar koopt in februari 2017 een appartement met berging in een appartementencomplex. In juli 2017, voorafgaand aan de levering, vraagt de vrouw aan de Vereniging van Eigenaars $(\mathrm{VvE})$ of zij haar scootmobiel in de hal onder de trap kan plaatsen en daar kan opladen. Het bestuur staat dit niet toe, omdat de Akte van Splitsing verbiedt om goederen in de gemeenschappelijke ruimte te plaatsen. Wel geeft het de vrouw een ontheffing van het verbod en zegt dat er plek is in de containerruimte, waar ze de scootmobiel kan stallen en opladen. Het bestuur legt dit besluit tot ontheffing van het verbod voor aan de leden van de VvE. Die stemmen in meerderheid (46 tegen 2) tegen het besluit van het bestuur. De vrouw krijgt daarom geen toestemming voor plaatsing van het voertuig in de containerruimte.

De vrouw neemt daar geen genoegen mee en verzoekt de kantonrechter om het besluit van de VvE te vernietigen. Ze beroept zich op de redelijkheid en billijkheid die in artikel 2:15 lid 1 sub b BW beschreven zijn. De kantonrechter wijst dit verzoek toe en de vrouw heeft daarmee toestemming verkregen om haar scootmobiel in de containerruimte te plaatsen.

Mr. D.C. (Dick) Houtzager is Senior Programmamanager bij ZonMw en hoofdredacteur van Handicap \& Recht.
De VvE gaat in hoger beroep tegen de beslissing van de kantonrechter en Hof Amsterdam buigt zich over de zaak.

\section{Arrest Hof Amsterdam}

De $\mathrm{VvE}$ brengt een aantal grieven naar voren, die het hof achtereenvolgens behandelt. Volgens de $\mathrm{VvE}$ is er voor de vrouw geen noodzaak om gebruik te maken van een scootmobiel, omdat zij kan lopen en trappen kan lopen. Het hof stelt vast dat de vrouw wel een scootmobiel nodig heeft, en verwijst naar een medische verklaring waaruit blijkt dat zij een mobiliteitsbeperking heeft. Ook heeft de vrouw een Wmo-besluit van de gemeente in het geding gebracht. Daarin staat onder andere dat de gemeente een Wmo-indicatie heeft afgegeven voor het verstrekken van een scootmobiel en voor het aanpassen van de algemene ruimte ten behoeve van de scootmobiel.

Het hof wijst ook het argument van de $\mathrm{VvE}$ af dat zij slechts een kleinere scootmobiel nodig heeft en niet van de omvang die zij gebruikt ten tijde van het VvEbesluit. Het hof verwijst daarbij naar een verklaring van de fysiotherapeut van de vrouw, waaruit volgt dat dat kleinere type voor haar in de praktijk niet geschikt bleek. Zij heeft niet alleen een scootmobiel nodig met vering (om voor haar pijnlijke schokken op te vangen), maar ook een met een zodanige omvang dat zij daarop met een gestrekt been kan zitten; zij kan haar been 
namelijk niet voor langer dan een paar minuten naar beneden houden. Verder heeft haar huidige (grotere) scootmobiel een grotere actieradius en verschaft deze haar daarom meer bewegingsvrijheid, hetgeen voor haar van wezenlijk belang is.

Vervolgens overweegt het hof of een $\mathrm{VvE}$ verplicht is om plaatsing van een scootmobiel in een gemeenschappelijke ruimte toe te staan. Het hof overweegt:

'3.5 Anders dan [geintimeerde] suggereert bepaalt artikel $6 \mathrm{~b}$ onder $\mathrm{d}$ Wet gelijke behandeling op grond van handicap of chronische ziekte niet, laat staan met zoveel woorden, dat de $\mathrm{VvE}$ verplicht is mee te werken aan plaatsing van een scootmobiel in de gemeenschappelijke ruimten. Bij de beslissing om al dan niet toestemming te verlenen de scootmobiel in de containerruimte te mogen plaatsen dient de ledenvergadering van de $\mathrm{VvE}$, die krachtens de Akte van Splitsing tot een dergelijke beslissing bevoegd is, op grond van artikel 2:15 lid 1 sub b BW de redelijkheid en billijkheid die artikel 2:8 BW vereist in acht te nemen. Beoordeeld moet daarom worden of de $\mathrm{VvE}$ bij het besluit die toestemming niet te verlenen, bij afweging van alle betrokken belangen in redelijkheid en naar billijkheid tot dat besluit heeft kunnen komen.'

Vervolgens beoordeelt het hof of er een reëel alternatief is voor het stallen van het voertuig. Daarbij wijst de $\mathrm{VvE}$ onder andere op de mogelijkheid om de scootmobiel in de eigen transportbus van het echtpaar te stallen. Het hof weegt de nadelen van dat alternatief af tegen de situatie van de stalling in de containerruimte en stelt:

'3.7.3 Het plaatsen van de scootmobiel in de transportbus van [geintimeerde] betekent dat de scootmobiel niet opgeladen kan worden, dan wel (en ervan uitgaand dat een laadpaal bij de invalidenparkeerplaats wordt geplaatst) slechts met het raam van de transportbus open. Het laden van de scootmobiel duurt volgens [geïntimeerde] ca. 10 uur. Ook moet [geintimeerde] dan de scootmobiel (van 174 kilo) voor ieder gebruik uit de bus halen en daar weer in terugplaatsen, hetgeen belastend voor haar is. Dit alternatief betekent voor [geïntimeerde] tevens dat het gebruik van haar transportbus aan beperkingen wordt onderworpen, onder meer omdat geen passagiers mee kunnen als - naast haar rolstoel - ook de scootmobiel steeds in de transportbus moet kunnen blijven.'

De vrouw parkeert de scootmobiel, na de beslissing van de kantonrechter, al een jaar in de containerruimte. In die tijd is niet gebleken van ruimtegebrek of blijvende problemen met het legen van de afvalcontainers door het afvalverwerkingsbedrijf. Ook is niet gebleken van brandgevaar of schade aan de scootmobiel zelf of andere voorwerpen. Het hof: 'De slotsom moet luiden dat de containerruimte een passende stallingsruimte voor [de vrouw]'s scootmobiel is en geen (noemenswaardige) nadelen voor de $\mathrm{VvE}$ met zich brengt.'
Dan volgt bekrachtiging van de beschikking van de kantonrechter met een geclausuleerde toestemming voor het plaatsen van de scootmobiel in de containerruimte.

\section{Commentaar}

1. Het plaatsen van een scootmobiel in een appartementengebouw: het is een toenemend fenomeen. We worden steeds ouder en blijven langer mobiel dan vroeger. Een vervoermiddel als een scootmobiel helpt daarbij. Het aantal scootmobielen neemt sterk toe: naar schatting rijden er ruim 250.000 in Nederland rond. ${ }^{1}$ Veel appartementengebouwen, zowel in de huur- als in de koopsector, zijn echter niet ingericht op het plaatsen en opladen van scootmobielen. Geschillen over de vraag waar een dergelijk voertuig geplaatst kan worden, komen dan ook frequent voor. ${ }^{2}$ Een scootmobiel is, anders dan een elektrisch voortbewogen rolstoel, een voertuig. Een dergelijk voertuig valt onder de regelingen van de Wegenverkeerswet. ${ }^{3}$ Hij is bedoeld voor gebruik op de openbare weg en is in het algemeen niet geschikt om zich binnenshuis op te verplaatsen. Het stallen in de woning ligt dan ook niet voor de hand.

2. In de onderhavige zaak weigert de ledenvergadering van een $\mathrm{VvE}$ om ontheffing te verlenen van het verbod om voertuigen in een gemeenschappelijke ruimte te plaatsen. In de aangespannen procedure komt het hof in hoger beroep tot de conclusie dat deze weigering in strijd is met de redelijkheid en billijkheid. Volgens artikel 2:15 lid 1 sub b BW moeten besluiten van rechtspersonen de toets van de redelijkheid en billijkheid kunnen doorstaan, anders zijn zij vernietigbaar. Dat geldt ook voor de toepassing van de regels in een splitsingsakte door de ledenvergadering van een $\mathrm{VvE}$.

De uitspraak van het hof is helder en overtuigend. De weigering van de $\mathrm{VvE}$ om af te wijken van de splitsingsakte kon, met de alternatieven die zij aandroeg, niet als redelijk of billijk worden aangeduid. De uitkomst van de procedure is dan ook bevredigend. Het arrest sluit aan bij een eerder arrest van Hof Arnhem-Leeuwarden, eveneens over de weigering van een $\mathrm{VvE}$ om plaatsing van een scootmobiel in een gemeenschappelijke ruimte toe te staan. ${ }^{4}$ Ook in dat arrest verwijst het hof naar de redelijkheid en billijkheid die in acht moeten worden genomen bij de toepassing van de splitsingsakte bij een appartementengebouw. Er lijkt zich daarmee een lijn in de jurisprudentie af te tekenen.

1. R. Davidse e.a., Scootmobielongevallen. Hoe ontstaan ze en hoe zijn ze te voorkomen?, R-2018-15, Den Haag: SWOV, p. 7

2. Het College voor de Rechten van de Mens heeft zich in een aantal zaken gebogen over dergelijke casus; zie CRM 5 maart 2010, oordeel 2010-35; CRM 25 februari 2011, oordeel 2011-30 en CRM 10 april 2018, oordeel 2018-33.

3. Zie art. 2 en 7 Reglement Verkeersregels en Verkeerstekens 1990.

4. Hof Arnhem-Leeuwarden 17 juni 2016, ECLI:NL:GHARL:2016:4889. 
3. In overweging 3.5 van het besproken arrest verwijst het hof naar artikel $6 \mathrm{~b}$ Wet gelijke behandeling op grond van handicap of chronische ziekte (WGBH/ CZ), waar de vrouw zich op beroept. In artikel $6 \mathrm{~b}$ onder $\mathrm{b}$ WGBH/CZ is bepaald dat onderscheid op grond van handicap of chronische ziekte bij het sluiten, uitvoeren, wijzigen of beëindigen van een overeenkomst betreffende het huren, kopen of bewonen van woonruimte voor eigen gebruik, verboden is. Het hof stelt dat dat artikel niet met zich meebrengt dat de $\mathrm{VvE}$ verplicht is mee te werken aan plaatsing van een scootmobiel in de gemeenschappelijke ruimten. Uit dat artikel vloeit niet een expliciete verplichting voort om het stallen van een scootmobiel in de gemeenschappelijke ruimte toe te staan, aldus het hof. Dat lijkt mij juist.

4. Dit betekent evenwel niet dat de WGBH/CZ geen rechtsbron kan zijn voor geschillen die over het plaatsen van scootmobielen gaan. In mijn visie zou het juist de voorkeur verdienen om de WGBH/CZ als rechtsbron te gebruiken.

5. Het is in dat verband de moeite waard te kijken naar artikel 2, in combinatie met artikel $6 \mathrm{a}, 6 \mathrm{~b}$ en $6 \mathrm{c}$ $\mathrm{WGBH} / \mathrm{CZ}$. In het systeem van die wet is geregeld dat een partij die huisvesting aanbiedt, dient te zorgen voor doeltreffende aanpassingen, tenzij dat een onevenredige belasting met zich meebrengt. Dat vloeit voort uit artikel $2 \mathrm{WGBH} / \mathrm{CZ}$. Het doel van die bepaling is dat de persoon met een beperking op voet van gelijkheid met anderen gebruik kan maken van een aangeboden dienst. ${ }^{5}$ Het weigeren van een dergelijke aanpassing kan verboden onderscheid opleveren. ${ }^{6}$ Aanpassingen zijn toegespitst op de individuele omstandigheden en kunnen bestaan uit bouwkundige of woontechnische aanpassingen in of aan de woonruimte (zoals het aanbrengen van een traplift) of om andere aanpassingen van fysieke aard. Daarnaast zijn aanpassingen mogelijk in reglementen, waaronder bijvoorbeeld de besproken casus valt: het verlenen van ontheffing door de $\mathrm{VvE}$ van het verbod voor plaatsing van goederen in gemeenschappelijke ruimtes.

6. Bij de invoering van de bepalingen over wonen in de WGBH/CZ, de huidige artikelen $6 a, 6 b$ en $6 c$ WGBH/CZ, heeft de wetgever een uitzondering gemaakt op het vereiste van het verrichten van een doeltreffende aanpassing. Hij verwees daarbij naar de invoering van de Wmo 2015. De bepalingen van de Wmo 2015 leggen gemeenten de plicht op om voorzieningen te bieden voor mensen die niet op eigen kracht, met gebruikelijke hulp, kunnen voorzien in zelfredzaamheid of participatie. Volgens de regering diende de gelijkebehandelingsplicht tot het verrichten van doeltreffende aanpassingen in het

5. Voor de uitleg van het recht op een doeltreffende aanpassing is van belang het arrest HvJ EU 11 april 2013, C-335/11 en C-337/11 (HK Danmark), ECLI:EU:C:2013:222, r.o. 48-64.

6. Zie bijvoorbeeld CRM 4 juli 2019, oordeel 2019-64, https:// www.mensenrechten.nl/nl/oordeel/2019-64 inzake de weigering om met een scootmobiel een bibliotheek te mogen betreden. kader van wonen te worden uitgezonderd indien het een bouwkundige of woontechnische aanpassing betreft. Dit 'om te voorkomen dat voor de huursector deze verplichting in de plaats komt van het door het gemeentebestuur verlenen van woonvoorzieningen op grond van de Wmo 2015. Voor de huursector zou dan de verplichting tot het treffen van bouwkundige of woontechnische aanpassingen verschuiven van de overheid naar de markt, de verhuurders.' ${ }^{7}$ Blijkens de memorie van toelichting bij de gewijzigde WGBH/CZ geldt de uitzondering dus niet voor niet-fysieke voorzieningen, zoals het aanpassen van een reglement. In de MvT is sprake van de huursector, maar de uitzondering geldt voor hele terrein van wonen. Daar valt ook de koopsector onder, inclusief de verhouding tussen een koper of bewoner van een appartement en de $\mathrm{VvE}_{\mathrm{v}}$.

7. Het weigeren van een niet-fysieke aanpassing hoeft geen verboden onderscheid op te leveren. Een belangrijke uitzondering op het verbod ligt in de bescherming van de veiligheid en de gezondheid. Als de veiligheid of de gezondheid aangetast worden door de plicht om een aanpassing te verrichten, geldt het verbod van onderscheid niet. In de MvT noemt de regering het volgende voorbeeld: 'Het plaatsen van een scootmobiel in de gemeenschappelijke ruimte kan in de akte van splitsing niet zijn toegestaan. De vereniging van eigenaren kan hiervan ontheffing verlenen. Het verlenen van ontheffing ligt in de rede indien een bewoner die in verband met zijn beperking een scootmobiel gebruikt, die scootmobiel in de gemeenschappelijke ruimte wil kunnen plaatsen. Mogelijk is echter dat het verlenen van ontheffing wordt geweigerd, bijvoorbeeld als de scootmobiel in die gemeenschappelijke ruimte de veiligheid of gezondheid van mensen in gevaar zou brengen (bijvoorbeeld bij brand). ${ }^{8}$

8. Zoals gezegd is de uitkomst van de uitspraak van het hof, namelijk dat de redelijkheid en billijkheid zich verzetten tegen de weigering om de scootmobiel op een geschikte plaats te stallen, bevredigend. Toch blijft de vraag of een combinatie van de artikelen 2 en $6 \mathrm{~b}$ en $6 \mathrm{c} \mathrm{WGBH} / \mathrm{CZ}$ in situaties als deze niet toegepast moet worden. Vastgesteld kan worden dat de $\mathrm{WGBH} / \mathrm{CZ}$ een lex specialis is ten opzichte van het $\mathrm{BW}$, de lex generalis. Toepassing van een lex specialis heeft voorrang op de lex generalis. Artikel $25 \mathrm{Rv}$ bepaalt dat de rechter de rechtsgronden moet aanvullen als daar een aanleiding toe is. In een geval waarin een partij of diens advocaat nalaat om een beroep op de WGBH/CZ te doen, dient de rechter deze wet toe te passen. Daarmee wordt meer recht gedaan aan het specifieke karakter van de plicht tot het treffen van aanpassingen: het geven van toestemming voor plaatsing van de scootmobiel.

7. Kamerstukken I/ 2013/14, 33990, 3, p. 10. Overigens verplicht art. 2.3.7 Wmo 2015 de eigenaar van een woning om toe te staan dat bouwkundige veranderingen worden aangebracht ten behoeve van Wmo-voorzieningen.

8. Kamerstukken // 2006/07, 30859, 3, p. 3. 
Bovendien kan het een rijker gemotiveerde uitspraak opleveren dan het toepassen van de redelijkheids- en billijkheidstoets. Immers, het onthouden van de toestemming levert onderscheid op. De vraag of het onderscheid verboden is, kan vervolgens nauwkeurig worden onderzocht aan de hand van de door de wetgever in de WGBH/CZ bepaalde criteria. ${ }^{9}$ Relevante vragen zijn daarbij: is de aanpassing geschikt en noodzakelijk om de belemmeringen die de betrokkene ondervindt op te heffen? Levert de aanpassing een onevenredige belasting op voor de aanbieder van woondiensten? Is de wettelijke uitzondering van veiligheid en gezondheid van toepassing? In mijn optiek wordt zo beter recht gedaan aan de bedoeling van de wetgever.

9. Overigens, het is onwaarschijnlijk dat de toets van de doeltreffende anpassing in dit geval tot een ander oordeel zou hebben geleid dan de redelijkheids- en billijkheidscriteria die het hof toepast. De ontheffing van het verbod op het stallen van de scootmobiel in de gemeenschappelijke ruimte lijkt me een redelijke aanpassing. Uit de feiten blijkt dat het voor de vrouw een noodzakelijke anpassing is, die belemmeringen opheft die ze ondervindt. Van een onevenredige belasting aan de kant van $\mathrm{VvE}$ lijkt geen sprake en, zo blijkt uit de feitenwaardering van het hof, de veiligheid of de gezondheid komt niet in het gedrang. 


\section{Dit artikel uit Handicap \& Recht is gepubliceerd door Boom juridisch en is bestemd voor anonieme bezoeker}

